\title{
SUSTAINABLE MANAGEMENT OF ECOTOURISM IN WESTERN RAJASTHAN, INDIA: A GEOSPATIAL APPROACH
}

\author{
Rajeev Singh CHANDEL \\ Suresh Gyan Vihar University, Centre for Climate Change and Water Research, \\ Jaipur, Rajasthan, India, e-mail: rajeev.52579@mygyanvihar.com \\ Shruti KANGA* \\ Suresh Gyan Vihar University, Centre for Climate Change and Water Research, \\ Jaipur, Rajasthan, India, e-mail: shruti.kanga@mygyanvihar.com
}

\begin{abstract}
Citation: Chandel, R.S. \& Kanga, S. (2020). SUSTAINABLE MANAGEMENT OF ECOTOURISM IN WESTERN RAJASTHAN, INDIA: A GEOSPATIAL APPROACH. GeoJournal of Tourism and Geosites, 29(2), 521-533. https://doi.org/10.30892/gtg.29211-486
\end{abstract}

\begin{abstract}
An Ecosystem is a community based of living organisms in conjunction with the non-living components in which people live without affecting their environment and Society. Development of ecotourism is not an isolated approach, so there is need to focus on that. Ecotourism thus implies a visit to an ecosystem for fun and adventure. Ecotourism, in true sense of the term, is not only travelling to such ecosystems but also conserving them and protecting the peculiar ethnicity and culture of the locality and wellbeing of the local inhabitants. In short, it is about uniting conservation, communities and sustainable travel. Ecotourism is the most important way for securing the tourism sector in sustainable way. The reputation of any country is depending on the tourism, education, employment, social values, cultural aspects, infrastructure, safety and security etc. The main objective of writing this paper is (i) Providing positive experiences for both tourists and local people; (ii) Providing sustainable development of the area and generating quality employment for the local people which fulfill their basic necessities; (iii) Respecting environment and cultural peculiarities of the area; (iv) Minimizing negative impact of tourists which ultimately enhance the tourism Industry.
\end{abstract}

Key words: Ecotourism Management, sustainable development, tourism, employment generation, experiences

\section{INTRODUCTION}

Ecotourism derived from two words "Eco" and "Tourism" in Eco means "Environment friendly" and Tourism means "Travel" (Jamal \& Stronza, 2009). Ecotourism continues to be embraced as the antithesis of mass tourism because of its promise of achieving sustainability through conservation mindedness, community development, education and learning, and the promotion of nature-based activities that

\footnotetext{
* Corresponding author
}

http://gtg.webhost.uoradea.ro/ 
were sensitive to both ecological and social systems (Fennell, 2015) (Figure 1). Rajasthan has a glorious place in the annals and geography of India the history of the state echoes with tales of chivalry, gallantry and brave deeds for, in their efforts to preserve Indian culture and heritage, the people of Rajasthan resisted all destructive or corruptive invasions from outside (Erlet, 1993). Western Rajasthan occupies significant place on the world map taking into consideration the most favored destinations of the tourist of the whole world. In Rajasthan, tourism is being commercially developed. Tourism here is culture (Kanga et al., 2014). That's why a large number of tourists visit Rajasthan which is most famous in the whole world for the magnificent strongholds atop the hills. Record number of tourists arrived in Rajasthan in the year 2006 (Sharma, 2008).

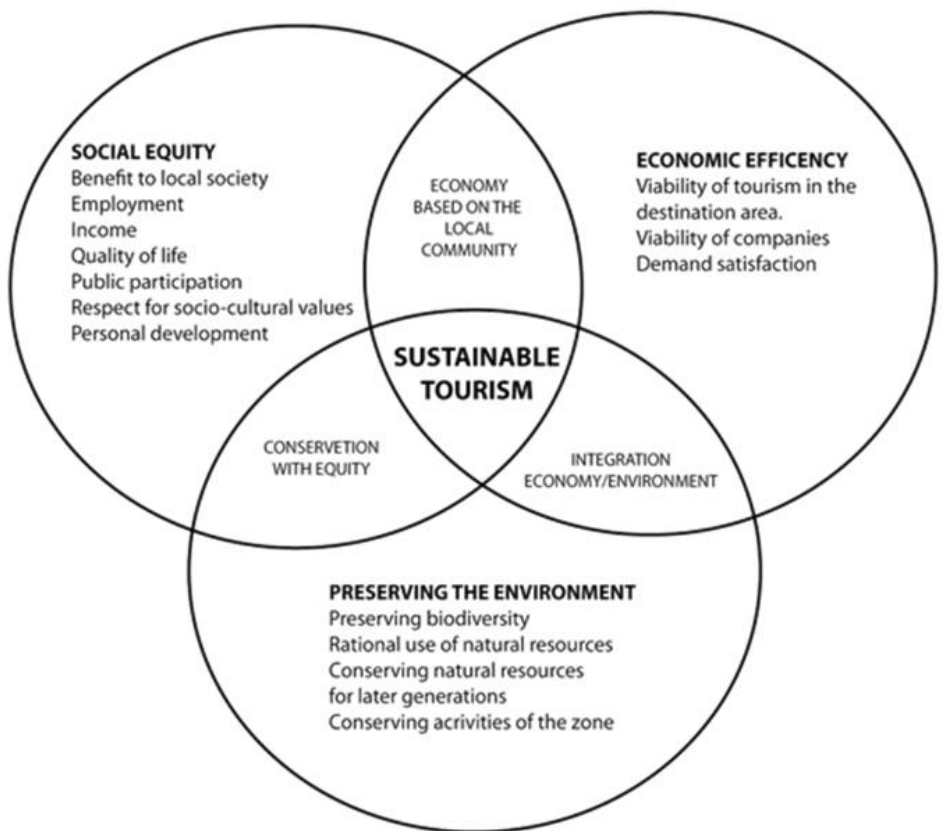

Figure 1. Sustainable Ecotourism Development Model (Source: Dorobantu \& Nistoreanu, 2012)

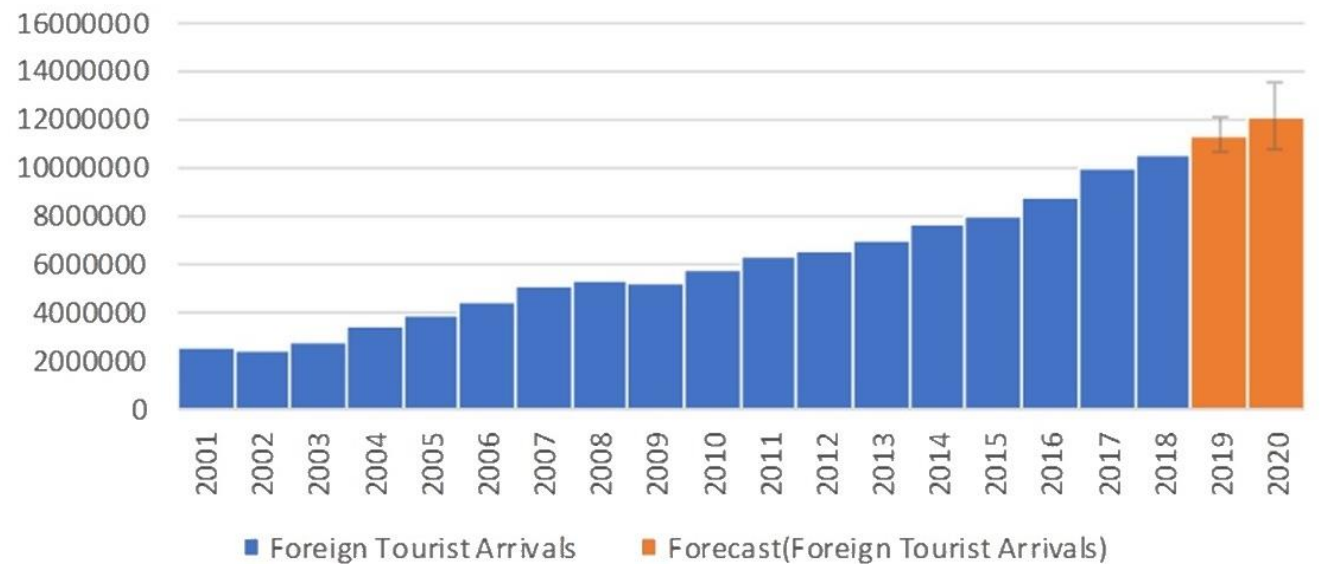

Figure 2. Foreign tourist arrivals year wise visits in India with forecasted data (Source: India Tourism Statistics 2018, Ministry of Tourism, India) 
Tourism is a growing industry in India, with people from all over the world traveling there to experience the country's natural beauty and visit its vast array of states and their differing cultures and climates (Chakrabarty \& Mandal, 2018). The largest number foreign tourist arrivals are usually seen in December and January during the cooler winter months when temperatures are more bearable (Figure 2). Tourism industry today has turned into a key driver of socio-economic progress (Kanga et al., 2013), through which the creation of jobs, enterprises and infrastructure development globally (Stausberg, 2012). Over the past six decades, tourism has experienced continued expansion and diversification, to become one of the largest and fastest-growing economic sectors in the world (Terzidou et al., 2008). Past years have seen the global Travel \& Tourism industry growing at a higher rate than significant sectors such as automotive, financial services and health care (Liu, 2003).

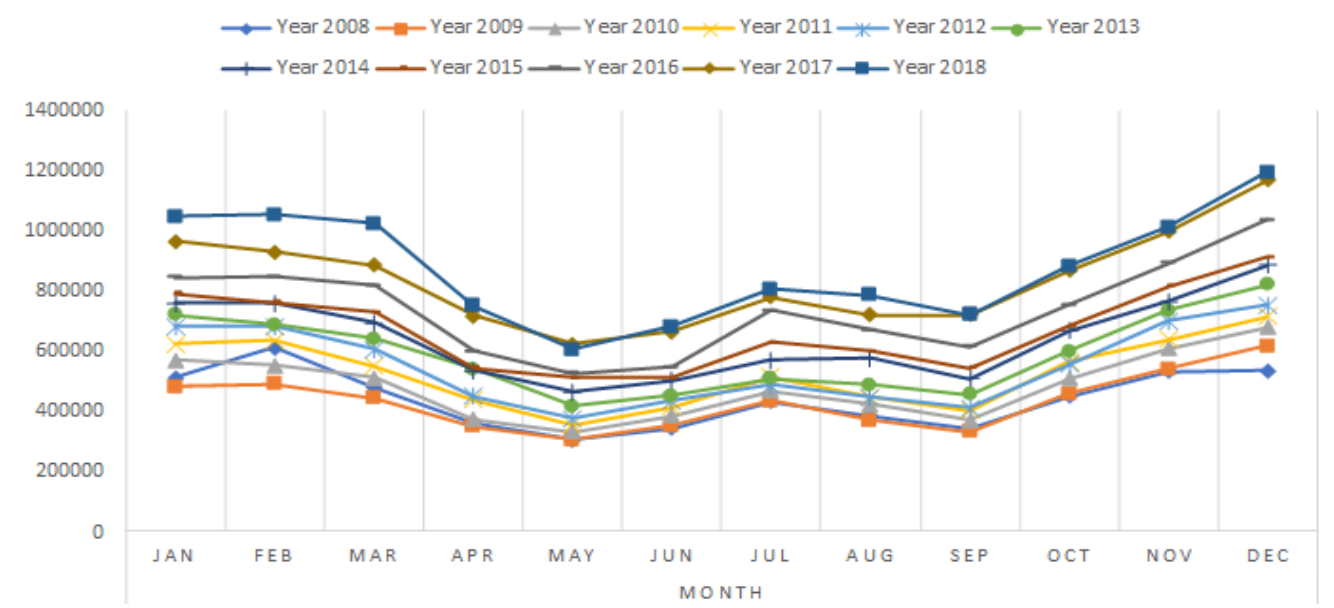

Figure 3. Foreign tourist arrival comparison monthly and year basis (Source: India Tourism Statistics 2018, Ministry of Tourism, India)

In 2016, India's tourism industry was expected to directly contribute 91.3 billion U.S. dollars to the country's economy, and this value was forecasted to rise to 148.2 billion by 2027. As per (Figure 3), tourism has been one of the biggest revenue generators for the state for a long time (Wearing \& Neil, 2009). According to the Ministry of Tourism, Rajasthan accounted for $2.7 \%$ of the tourists in the year 2013. Rajasthan accounted for $7.2 \%$ of the total international tourist arrivals in India in the same year. Historic palaces, especially those in Jaipur and Udaipur, offer opportunities to expand the luxury ecotourism segment (Singh Chandel \& Kanga, 2018). Moreover, tourists visit wild life sanctuaries and desert locations for the exclusive experience they provide. In Rajasthan, tourism accounted for $2.7 \%$ (5.2\% after adding indirect effects) in Gross State Domestic Product and 1.9\% (7.2\% after adding indirect effects) in state employment. The industry of tourism is rapidly becoming the leading of economic in the most developing countries (Singh et al., 2017). Many governments pay a lot of money to develop and expand this sector to be a major source for the development of economy in their countries. Furthermore, those governments tray to make their tourism places fully marketed and explored.

\section{STUDY AREA}

Western Rajasthan is one of the major parts of the Rajasthan in terms of ecotourism. Ecotourism is today's necessities for future generation. Western Rajasthan mainly include Four District Bikaner, Barmer Jaisalmer \& Jodhpur (Figure 4). Some facts of four district are as follows: 


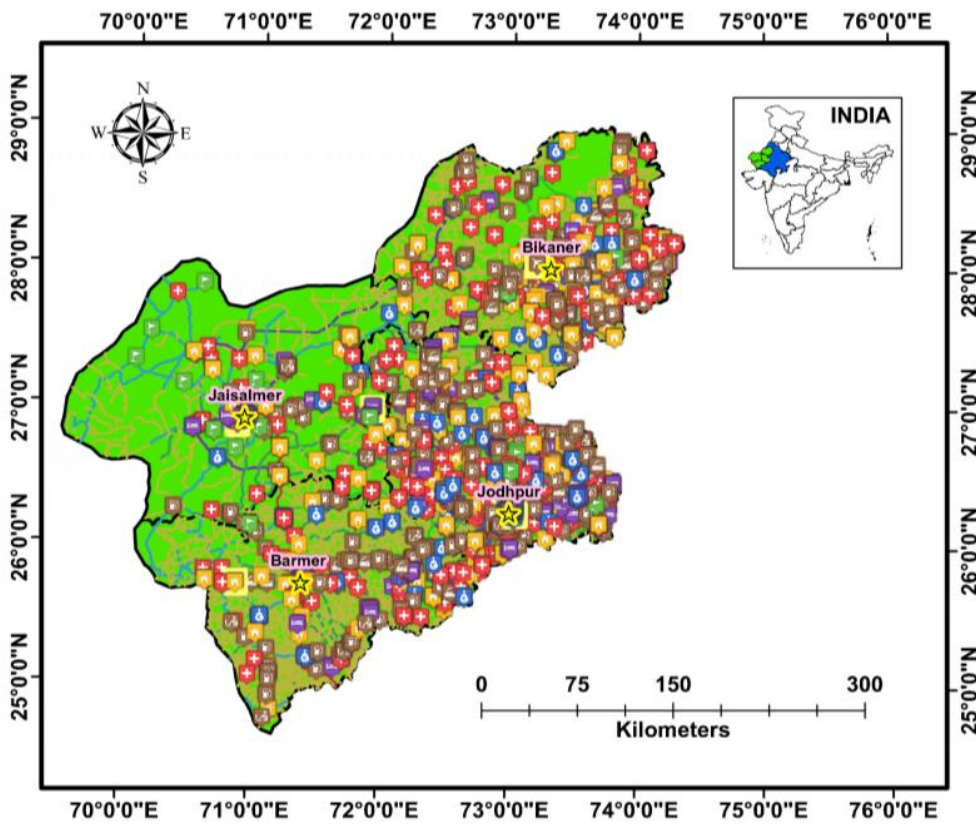

\section{LEGENDS}

is District $\mathrm{HQ}$

[d] ATM

(4) Banks

(14) Domestic Airport

[. Fuel Filling Station

+ Health

a Helipad

Hotel

(4) Police Station

2) Railway Station

Tourist Spots

Study Area

Road Network

— Major District Roads

- National Highway

- Other District Roads

Other Roads

State Highway

Village Roads

Figure 4. Location Map of Western Rajasthan

\section{Geographical Features}

The arid and forbidding Thar Desert lies in north-west Rajasthan and is characterised by shifting sand dunes and high summer temperatures of up to $45^{\circ} \mathrm{C}$ (Figure 5). Jodhpur lies on the edge of this arid tract and is the link between the desert on the west and the semi-arid but cultivable regions to the East (Sharma \& Bisht, 2018). The region receives very little rainfall - 90\% of it in the monsoon (July-September) (Figure 6). As per census population of Jodhpur is more than 10 lakhs which is the largest city in the region. It is also the second largest city in the state. Other important cities in the region include Bikaner 6 lakhs, Barmer 96 thousand and Jaisalmer has 65 thousand (Wearing, 2011). The Desert circuit is the largest though the most sparsely populated region in the state. Given the climatic profile of the Desert circuit the tourist season is limited to the winter months and almost the entire tourist traffic comes from October to March.

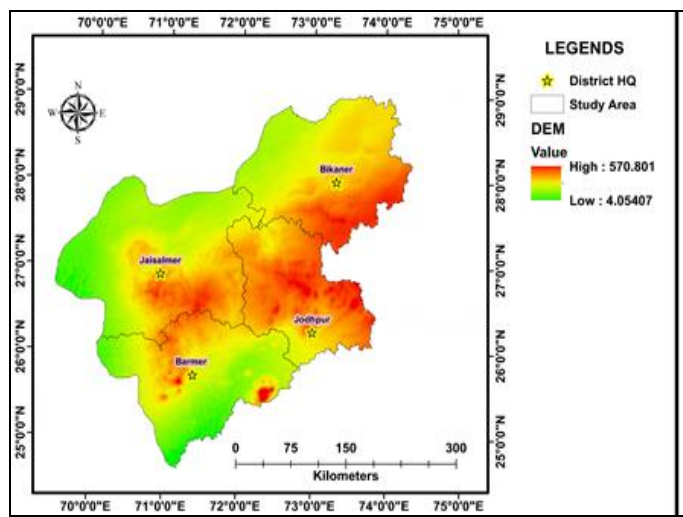

Figure 5. Elevation Map

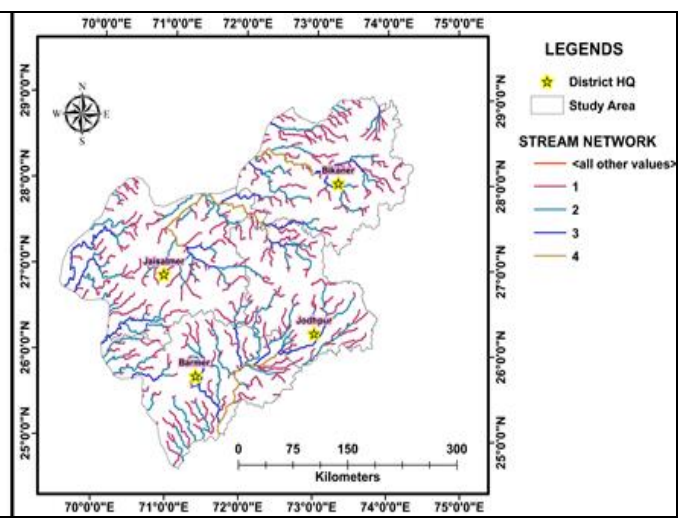

Figure 6. Stream Network Map 
Travel Link: Jodhpur Civil Aerodrome (located $4 \mathrm{Kms}$ from the city centre) is the only airport in the Desert region with daily commercial passenger flights operated by Alliance Air, and Jet Airways from Delhi, Mumbai, Jaipur and Udaipur. Commercial air services to the other airport within the region - Jaisalmer have been temporarily discontinued recently given its sensitive position near the forward areas.

A well-developed broad-gauge rail network connects the Desert region to the main cities in the country. There are regular train services between Jodhpur and Bikaner to cities like Delhi, Mumbai, Kolkata, Chennai and Bangalore. Onward connections to Jaisalmer are available ex-Jodhpur. The Desert region is also well connected by roads with NH15 passing through Bikaner, Jaisalmer and Barmer. Jodhpur is connected to all the three places by state highways and district roads.

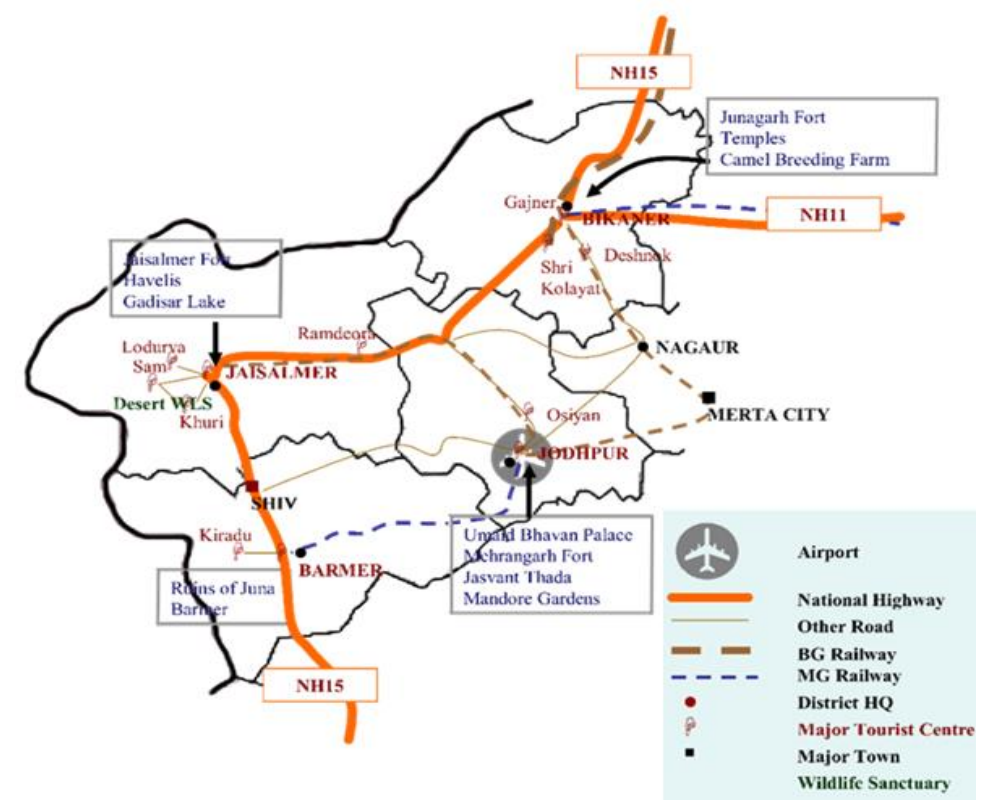

Figure 7. An Important Tourism Circuit of Western Rajasthan

\section{Major Tourist Spots and Attractions}

The major tourist locations and attractions in the Desert circuit (Figure 7). The region has several tourist attractions, though the most popular are in and around Jodhpur, Jaisalmer Bikaner and Barmer. Unlike most other circuits in the state, the Desert circuit does not have one particular 'hub' though Jodhpur is the most popular entry point. Given the large geographical area covered by wide road network (Figure 8), the major cities in the region are hubs for the tourist undertaking local excursions. Some salient observations with respect to the main tourist locations and the type of tourists they attract are as follows:

- Jodhpur: Jodhpur, one of the principal cities in the circuit, has the massive $15^{\text {th }}$ century Mehrangarh fort. The city also houses the grand Umaid Bhavan palace (and hotel), the only 2oth century palace. Other attractions include the beautiful white marble royal cenotaphs of Jasvant Thada and the ancient capital of Marwar, Mandore with its cenotaphs and gardens. Another emerging destination, around an hour's drive from the city is the Osiyan village, which houses 15 beautifully sculpted Jain and Brahmanical temples belonging to five different centuries. 
- Jaisalmer: Jaisalmer, the golden city of Rajasthan, is one of the favourite destinations for both domestic and foreign tourists. The main attraction is the Jaisalmer fort, which houses an entire living area within its ramparts and is known for its beautifully carved forts and its ancient Jain temples. Attractions outside the fort, are the intricately carved forts such as the Patwon ki Haveli* and the Salim Singh ki Haveli* and the Gadisar Lake. Other famous attractions ex-Jaisalmer include the Lodurva Jain temples, Sam sand dunes, the Desert National Park and the Khuri village safari. The popular tourism 'products' of the region include the desert village camps, desert safaris and the desert festival.

- Bikaner: Bikaner lies at the northern most point of the desert circuit, and is famous for its forts, palaces and forts. Places of tourist interest include the Junagarh fort and museum and the Lallgarh palace. Other attractions are the Camel Research Farm and the Bhandeshwar and Sandeshwar temples (visited by the domestic tourists). The popular excursions from this city include the famous Karni Mata temple (at Deshnok), the Gajner Palace and wildlife sanctuary and Shri Kolayat temple.

- Barmer: A small desert town, Barmer is famous for its carved wooden furniture and hand block printing. It is best visited during the annual fairs held nearby. The places of interest in this region include the ruins of Juna Barmer and the Kiradu temples. Other places in the district like Khed and Jasol are also known for their temple architecture.

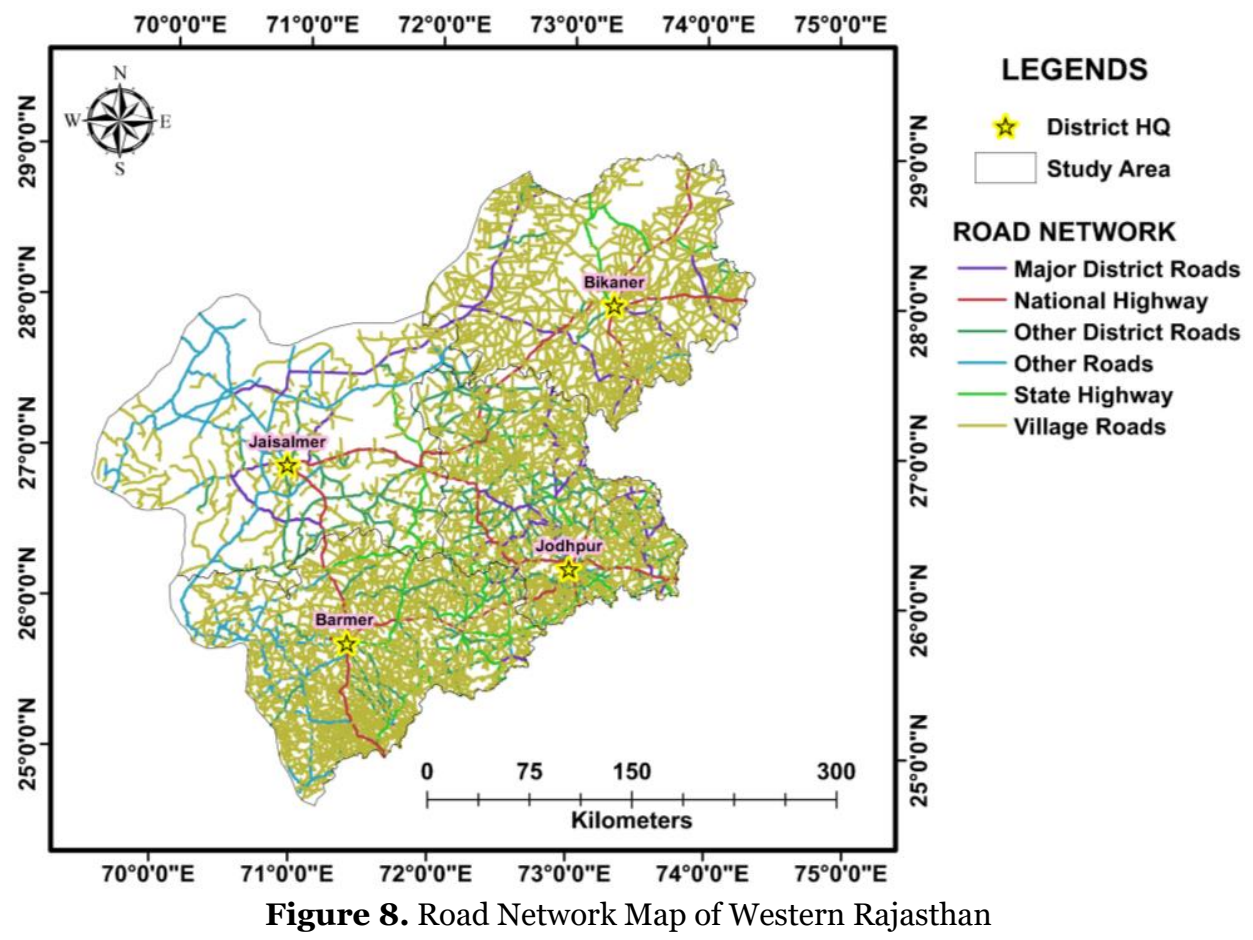

\section{Objectives of the study}

The main objectives of writing this paper are: (i) Providing positive experiences for both tourists and local people; (ii) Providing sustainable development of the area and generating quality employment for the local people which fulfill their basic necessities; (iii) Respecting environment and cultural peculiarities of the area; (iv) Minimizing negative impact of tourists which ultimately enhance the tourism Industry. 


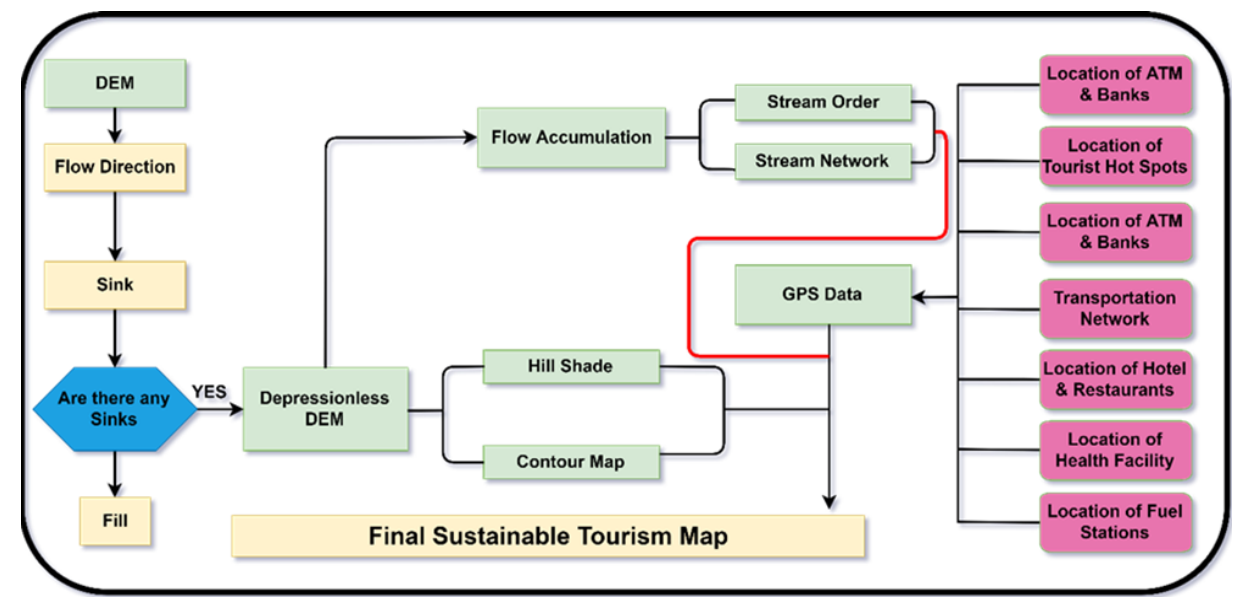

Figure 9. Methodology Adopted

\section{Database and Methodology}

As per the latest statistics of Directorate of Economics and Statistics, Planning Department, Government of Rajasthan (2018), total geographical area of Rajasthan is 342239 sq.km encompassing $11 \%$ of the total geographical area of the country. In which western Rajasthan covers nearly $116882 \mathrm{sq}$. km (Figure 10-15). Approximately an area of $32,737 \mathrm{sq}$. $\mathrm{km}$ which is $9.57 \%$ of the total geographical area of the Rajasthan is covered by the forest. The Methodology adopted is shown in (Figure 9).

Jodhpur: Jodhpur, one of the largest districts is situated in the western part of the Rajasthan state. The average elevation of the city from mean sea level is $250-300$ meter. It is situated between north latitude and between east longitude, covering geographical area of $22850 \mathrm{sq}$. kms. It is bounded in the east by Nagaur district, West by Jaisalmer district, North by Bikaner districts and Barmer as well as Pali on Southern side. The Climate of Jodhpur is extremely hot and arid. The summer season is from April to June followed by rainy season from July to mid-September. The winter season is from November to March. The annual average rainfall is 366 millimetres, but this is not uniform throughout the year. The city receives most of the rain during monsoon season. The temperature shoots up in summer and drops in winter. The average annual rainfall in the city is 351 millimetres. Nearly $80 \%$ of the rainfall is received during the south-west monsoon season. The variation in the annual rainfall from year to year is very large in the year 2007 the average rainfall was $204 \mathrm{~mm}$, whereas in the next year it was $482.4 \mathrm{~mm}$.

Jaisalmer: Jaisalmer largest district of Rajasthan and one of the largest in the country is located within a rectangle lying between $26^{\circ} .4^{\prime}-28^{\circ} .23^{\prime}$ North parallel and $69^{\circ} .20^{\prime}-72^{\circ} .42^{\prime}$ east meridians. The width (East-West) of the district is $270 \mathrm{Kms}$ and the length (North-South) is $186 \mathrm{Kms}$. In present map, district Jaisalmer is bounded on the east by Jodhpur and Bikaner Districts, on the west \& south-west by Indian boarder, on the north by Bikaner and on the south by Barmer and Jodhpur. The length of international boarder attached to District Jaisalmer is nearly about $471 \mathrm{Kms}$. Jaisalmer District, comes under Great Indian Thar Desert, is sandy, dry and scorched. About 60 $\mathrm{kms}$ of radius is formed of stony and rocky terrain like structure of the district. Areas comes under Jaisalmer is barren, undulating with its famous sand dunes and slopes towards the Indus valley and the Runn of Kutch. It has a very dry climate with very hot summer; a cold winter and sparse rains. The climate is extremely hot during summer with maximum temperature reaching up to $49.2^{\circ} \mathrm{C}$ and extremely cold during winder with minimum temp. in the range of $1^{\circ} \mathrm{C}$ (Jhajharia et al., 2014). Due to this variation in 
temperature from morning to noon and the late midnight is a sudden phenomenon. The average rainfall is only $16.4 \mathrm{~cm}$ as against the state average of $57.51 \mathrm{~cm}$.

Bikaner: This district is spread across an area of $30,247.90 \mathrm{sq} \mathrm{km}$, the fourth largest city of Rajasthan and is located between $27^{\circ} 11^{\prime}$ and $29^{\circ} \mathrm{O} 3^{\prime} \mathrm{N}$ and $71^{\circ} 54^{\prime}$ and $74^{\circ} 12^{\prime}$ E. Rao Bika, a Rajput ruler in $1486 \mathrm{AD}$ founded the district headquarter. Bikaner has an extremely hot and arid climate is located in the middle of the Thar desert. During summers, the temperature of the region goes beyond $45^{\circ} \mathrm{C}$ during the day and in winters it dips down below $\mathrm{O}^{\circ} \mathrm{C}$ during the night. Bikaner faces annual rainfall between 260 to $440 \mathrm{~mm}$.

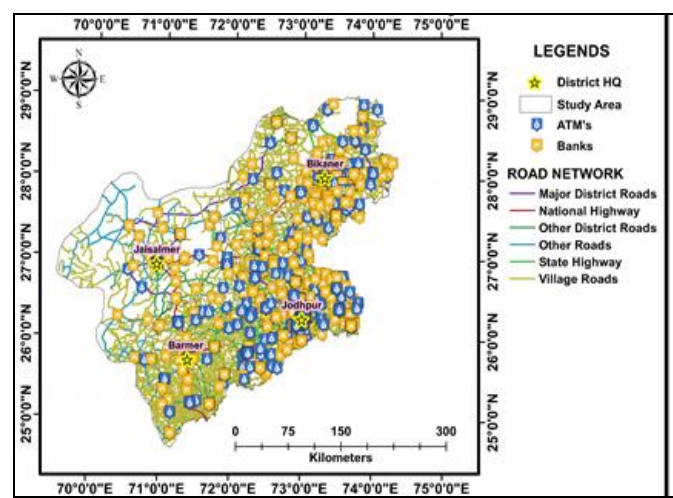

Figure 10. Bank \& ATM Map

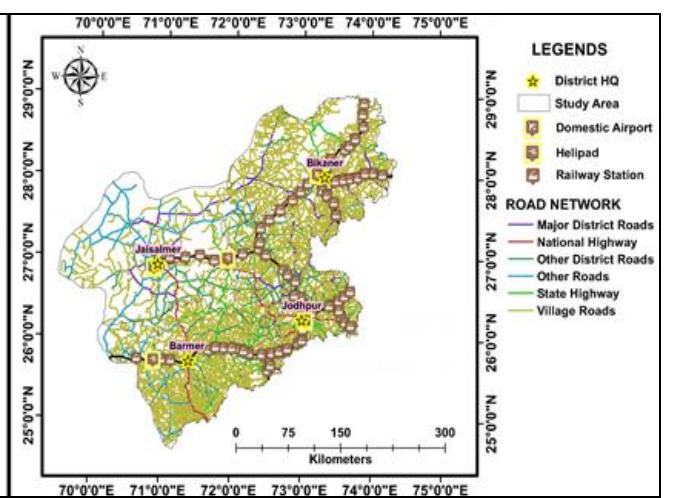

Figure 11. Transportation Map

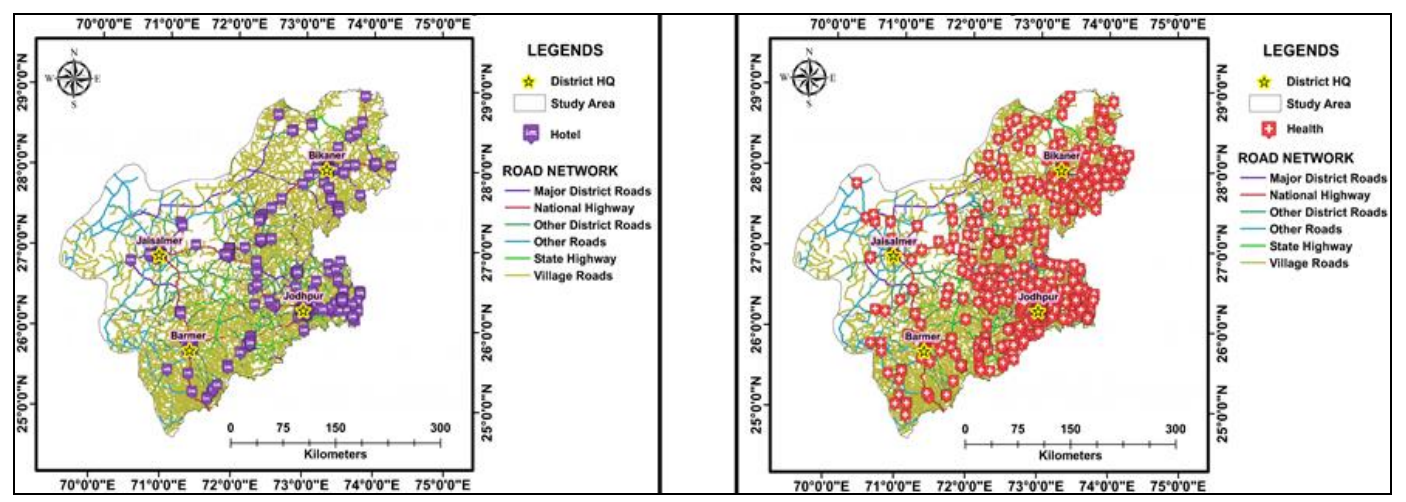

Figure 12. Hotel \& Restaurant Map

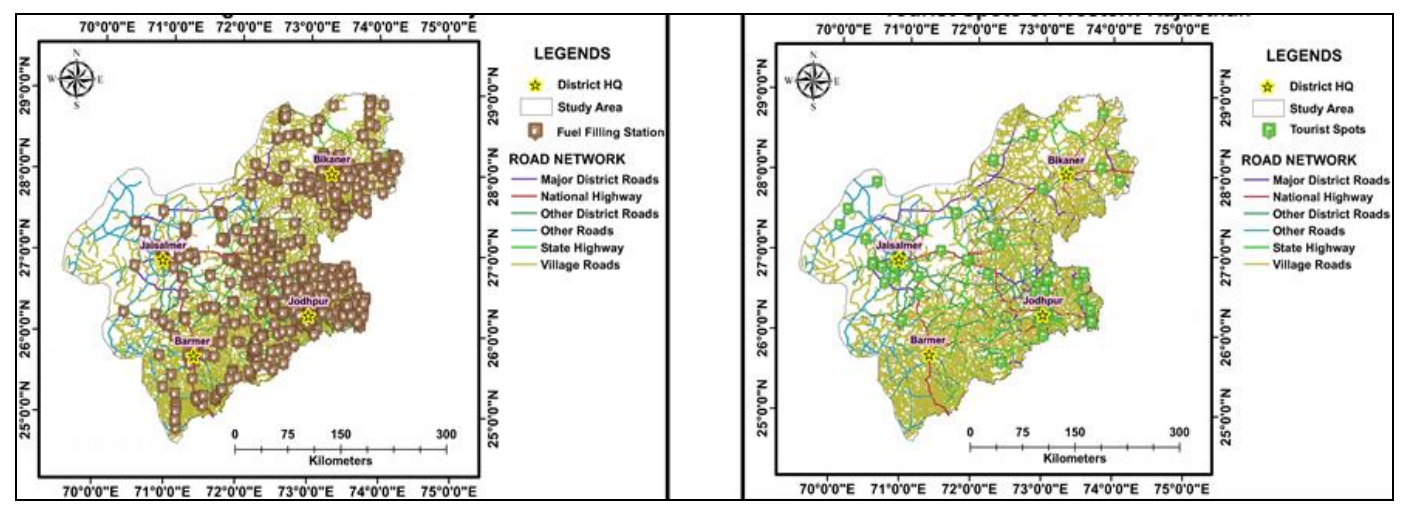

Figure 14. Fuel Filling Station Map

Figure 15. Major Tourists Spots Map 
Barmer: Barmer spread across an area of $28,387 \mathrm{sq} \mathrm{km}$, this district is the third largest district of Rajasthan located between $24^{\circ} 58^{\prime}$ and $26^{\circ} 32^{\prime} \mathrm{N}$ and between $70^{\circ} \mathrm{O} 5^{\prime}$ and $72^{\circ} 52^{\prime} \mathrm{E}$. The district forms a part of the Thar Desert and is situated in the western part of the state and shares its borders with Jaisalmer in the north, Jalore in the south pali and Jodhpur in the east, Pakistan in the west. Main river of the district is Luni river which is $480 \mathrm{~km}$ in length and meets at the Gulf of Kutch flowing through Jalore. Average annual rainfall of the region is nearly $277 \mathrm{~mm}$.

\section{Data \& Software Used}

During the study both primary and secondary data has been used. During the study primary data has been created in the form of vector map of Western Rajasthan which mainly includes four district Jodhpur, Jaisalmer, Bikaner \& Barmer using ArcGIS 10.7 and on the other hand, secondary has been collected from published and unpublished sources mainly from Department of Tourism, Rajasthan as well as from all the four district websites (Figure 16). The published data has been collected from different government agencies, municipal corporation, department of tourism, railway department, department of transportation and other non-government agencies etc.

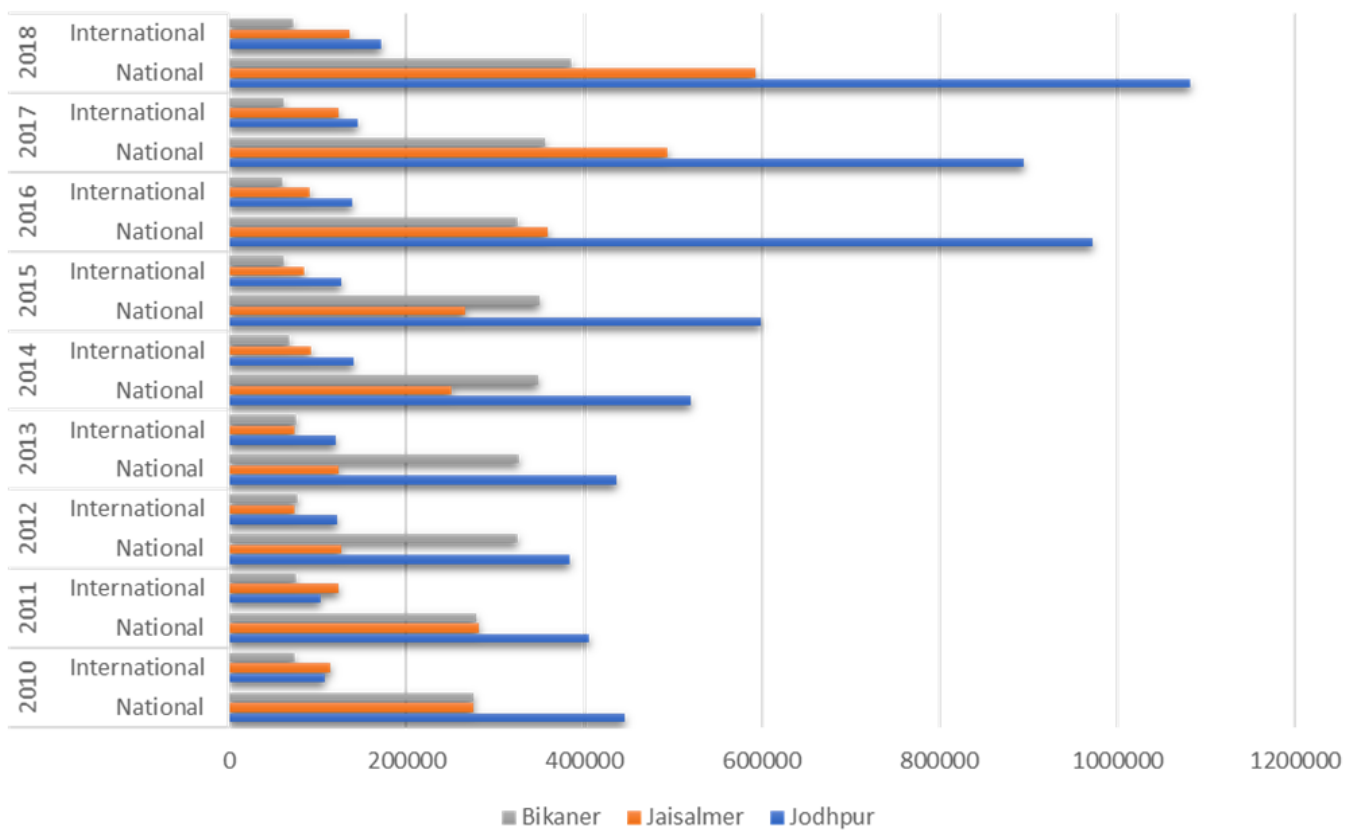

Figure 16. Tourist Arrival Trends of Western Rajasthan (Source: Department of Tourism, Rajasthan)

\section{Domestic Tourist Traffic}

The domestic traffic is highest in Jodhpur city ( $\sim 4.5$ Lakhs) followed by Bikaner $(\sim 1.9$ Lakhs) and then Jaisalmer ( $\sim 1$ Lakhs). Although Jaisalmer traditionally ranks behind Jodhpur and Bikaner in terms of domestic tourist arrival numbers, it has recorded an impressive $5 \%$ growth in domestic arrivals in the past five years. The other cities have either shown a decline or have grown at a lower rate during the same period. Though there are other tourist spots in the region such as Barmer, Osiyan, etc. none of them currently have significant tourist traffic (Strydom et al., 2019). Osiyan is rapidly gaining popularity amongst domestic tourists. Similarly, Barmer as well as others places such as Ramdeora, Deshnok, Kolayat record good domestic tourist arrivals during the fairs and festivals in these places. 


\section{Foreign Tourist Traffic}

Jodhpur receives the highest number of foreign tourists and has also shown $8 \%$ growth in the number of tourist arrivals in the past years. Bikaner has also recorded a $9 \%$ growth in the number of foreign tourists, although it ranks behind both Jodhpur and Jaisalmer currently. Jaisalmer, the traditionally popular destination with the foreigners has, however, shown a decline in the number of arrivals in the same period. This decline is attributed to its proximity to the Pokhran nuclear test site, and to the India-Pakistan border. Besides, both Jodhpur and Bikaner are offering tourists new products such as the desert and village safari packages that traditionally originated ex-Jaisalmer.

\section{Main Findings}

The main tourist traffic trends in Rajasthan over the past 5 years are as follows:

\section{Slow Growth in tourism in the main tourist locations}

The main tourist cities of Rajasthan namely, Jaipur, Udaipur, Jodhpur, Jaisalmer, Bikaner and Mount Abu have seen marginal growth (and occasionally a marginal decline) in total tourist traffic and all these locations (barring a few exceptions) have seen tourist traffic levels in 2001 largely unchanged from 5 years ago (1997).

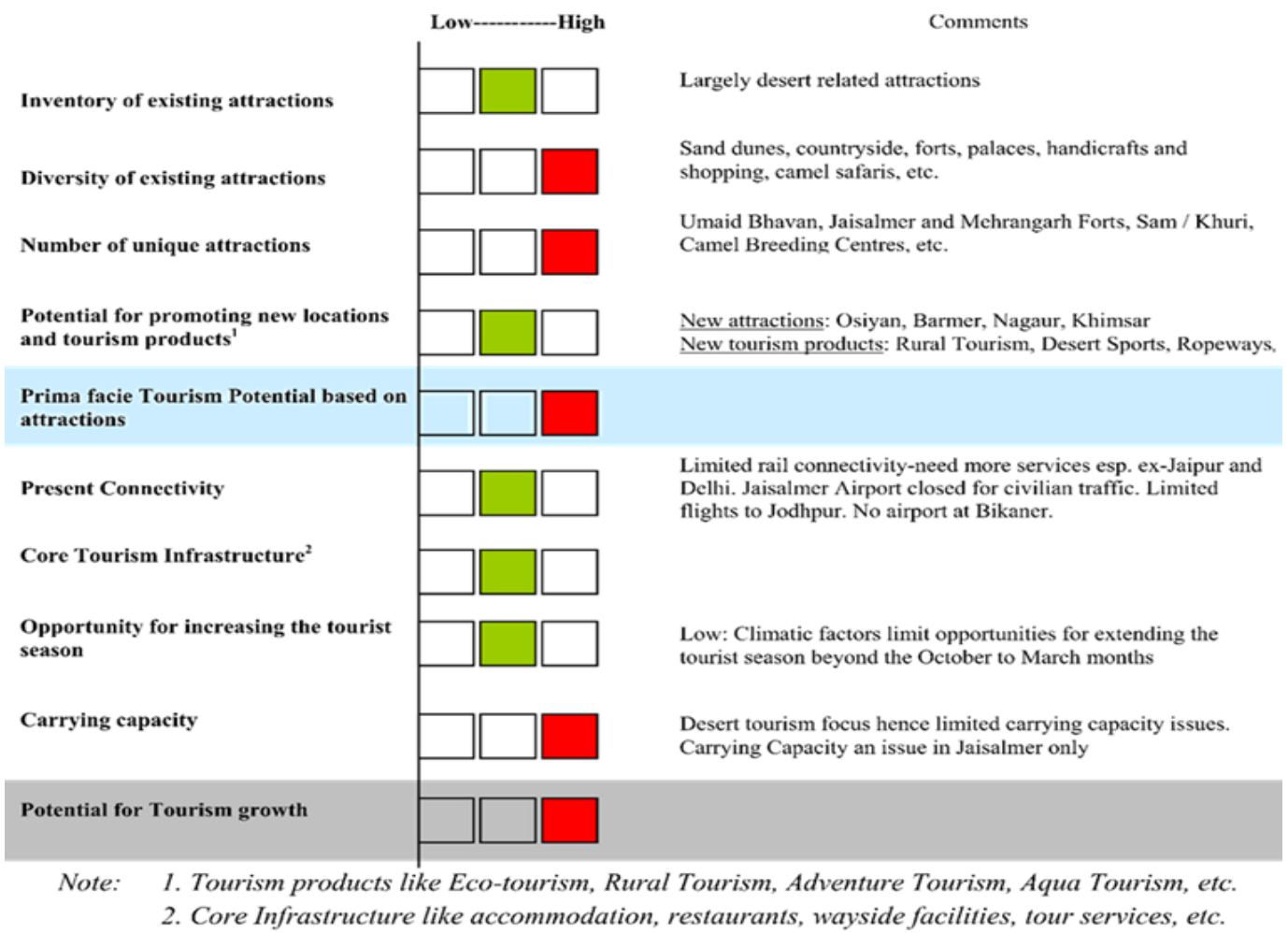

Figure 17. Evaluation of Potential for Tourism Growth

\section{Select Tourist locations are experiencing high growth}

In particular, the Ajmer- Pushkar circuit is experiencing high growth in domestic tourists - while foreign tourist traffic at these locations is more or less static, domestic tourist traffic has increased significantly particularly at Ajmer. Also, the Alwar-Sariska belt is experiencing strong growth. Growth in domestic tourism is largely due to its increasing popularity as a weekend gateway from Delhi (as well as a 'conference tourism' venue) while 
growth in foreign tourist traffic is led by the growing popularity of the Sariska WLS amongst foreigners who visits Jaipur and / or cover the Golden Triangle circuit. Amongst the smaller tourist destinations, especially Bundi (it is a part of the Hadoti circuit) has seen a tremendous increase in both domestic and foreign tourist traffic (Figure 17). Banswara (also Dungarpur) is slowly emerging on the tourist map though it should be noted that taking Banswara as an example traffic is led by the annual religious festivals / fairs.

- The ecotourism experience sought from Rajasthan is changing: Traditionally the Rajasthan ecotourism experience offered palaces, forts, lakes and the desert. However, based on the 5-year trend in tourist traffic, the experience sought from Rajasthan is changing. The traditional ecotourism experience is no doubt desired but the focus is gradually shifting to more varied ecotourism products particularly:

$\checkmark$ Wild life ecotourism (particularly the Sanctuaries)

$\checkmark$ Weekend ecotourism / conference ecotourism (particularly in Northern Rajasthan given its proximity to Delhi and NCR)

$\checkmark$ Value-added desert ecotourism (including adventure ecotourism, desert safaris, desert sports, etc.)

$\checkmark$ Newer (less 'touristry') destinations offering the same traditional experience (e.g. Bundi, distant heritage hotels, etc.)

- Domestic tourists are gradually becoming more important than foreign tourists: More so since in the last few years (and particularly in 2001) foreign tourists have been static while domestic tourists have grown.

Table 1. Ecotourism Relevant Infrastructure in Desert Circuit

\begin{tabular}{|c|c|c|c|c|}
\hline \multirow{2}{*}{ Category } & \multirow{2}{*}{ Current Status } & \multicolumn{3}{|c|}{ Potential for Development } \\
\hline & & Short Term & Medium Term & Long Term \\
\hline \multirow{2}{*}{ Connectivity Infrastructure } & \multirow{2}{*}{ Fairly developed } & $\boldsymbol{V}$ & $\mathbf{V}$ & $V$ \\
\hline & & \multicolumn{3}{|c|}{ In line with traffic growth } \\
\hline \multirow{2}{*}{ Accommodation } & \multirow{2}{*}{$\begin{array}{c}\text { Moderately } \\
\text { developed }\end{array}$} & $\boldsymbol{V}$ & $\boldsymbol{\alpha}$ & $\boldsymbol{V}$ \\
\hline & & \multicolumn{3}{|c|}{ Capacity in the mid-range segment } \\
\hline Midway/ Wayside Facilities & Fairly developed & $\checkmark$ & & \\
\hline Tourist Offices & Adequate & $\boldsymbol{V}$ & & \\
\hline \multirow{2}{*}{$\begin{array}{l}\text { Others (Recreational } \\
\text { Facilities, Shopping } \\
\text { Facilities, etc) }\end{array}$} & \multirow[b]{2}{*}{ Adequate } & $\boldsymbol{V}$ & $\boldsymbol{V}$ & $\boldsymbol{V}$ \\
\hline & & \multicolumn{3}{|c|}{$\begin{array}{l}\text { Organised shopping facilities retailing the } \\
\text { local art/ handicrafts/ textiles, etc. }\end{array}$} \\
\hline $\begin{array}{c}\text { Monuments/ Site } \\
\text { Enhancement }\end{array}$ & $\begin{array}{l}\text { Moderately } \\
\text { developed }\end{array}$ & $\boldsymbol{v}$ & 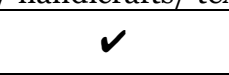 & and \\
\hline Sanctuaries/ Eco-Tourism & Not developed & $\boldsymbol{V}$ & & \\
\hline $\begin{array}{c}\text { Tourism Products (Rural } \\
\text { Tourism, Resort Tourism, } \\
\text { Health Tourism, etc) }\end{array}$ & Not developed & $\boldsymbol{V}$ & $\boldsymbol{V}$ & $\boldsymbol{\nu}$ \\
\hline
\end{tabular}

\section{CONCLUSION AND RECOMMENDATIONS}

Western Rajasthan has very huge potential to generate tourism at vast scale. It has variety of tourism places to attract tourist globally. But there is a need to focus by the government to give some subsidiary policy to encourage the tourism sector. By boosting the tourism, it creates more possibilities to the state for generating revenue and employment in different form. In some way development of world class tourism destinations in Western Rajasthan in an integrated manner to provide options to the discerning tourist, to attract investments and generate employment for local people. The smooth implementation and operations of tourism projects by facilitating initiatives in the area of land, human resources development, marketing and promotion and environment improvement. Based on the analysis of this report we can say that 
enhancement of ecotourism will give positive experience in between tourists and local people and it also helps in quality employment generation some of the key recommendations for the ecotourism sector:

Policies in Ecotourism: One of the basic initial steps is to have a dedicated state ecotourism policy which outlines how the states would like to project themselves. The prime focus on government policies, specific interventions proposed and planned, new and existing incentives to developers and private players and the vision for development of ecotourism in the state, among others for revenue generation (Chandel, 2013). A comprehensive and robust ecotourism policy is the first step towards achieving the desired tourist inflow for any state.

Road, Rail, Air Connectivity: The State Governments mainly focus on inter as well as intrastate connectivity. The improvement of regional connectivity is today's need and want of tourist for better ecotourism development. The suggested steps must speedily launch of the proposed high-speed passenger trains, constructing new and improving existing rural roads, identifying air strips to be converted into small commercial airports, renovating existing domestic airports into international airports and setting up heliports in select key states which experience more foreign tourist inflow. Inland waterways are another option to explore and improving the connectivity between cities and states.

Facilities for Tourists: One of the main requirements for the foreign tourists is the easy availability of the visa offices and centres at all the key destinations experiencing high foreign revenue. Apart from ensuring basic facilities such as sanitation and drinking water, efforts should be channelized towards provision of parking and way side facilities to improve ecotourism.

Employment for the People: There is an increased focus in many states on the MICE (Meetings, Incentives, Conferences and Exhibitions) sector as an engine of growth for the business in tourism sector. The availability of a number of options across all the cities which are connected through international airports is line with the demand for tourism sector. However, it's a need of today to have a separate strategy to devise and take necessary steps towards leveraging the MICE sector in main cities which are currently not internationally connected since they are facing hard competition from the other cities. Apart from connectivity, next focus on the availability of world-class infrastructure is another area of intervention like as setting up international level convention centers for the peoples. There is a need to take initiatives from the government side to provide incentives and subsidies to attract various investors may be proposed as part of the MICE (Meetings, incentives, conferences and exhibitions) strategy for the betterment of the tourism sector.

Facilities of Accommodation: India has some of the best luxury hotels and resorts in the world however there are some unexplored destinations which need to upgrade their service levels as well as increase the number of hotels. Secondly Introduction of theme-based resorts and hotels are mainly new options to be explored further in such destinations from the point of view of ecotourism. Some popular themes could be wild life resort, golf resorts, green as well as clean technology resorts in short eco-friendly means ecotourism can facilitate people etc.

Partnership between Public and Private: The higher government authorities of districts need to collaborate and explore the best and possible opportunities to attract tourists by offering wide and comprehensive services as well solutions. This could be done by collaborating with other states and countries for offering custom made experiences and services to the tourists. To create and enable ecotourism-based environment, there is a need to explore more opportunities by government for the enhancement of tourism sector and this can be done proper road map of creating and implementing tourism policies.

Keeping in view the region's colourful culture, Western Rajasthan has a huge potential of ecotourism which needs to be developed further. Some of the potential areas are as follows: 
$\checkmark$ Improving Intra State Air connectivity: There are currently chartered flights which help in connecting the cities of Rajasthan however they are not cost effective. To improve ecotourism prospects more focus needs to be given to this area.

$\checkmark$ Special desert tours for enthusiasts who want to know about the culture and history of the region (Local people in collaboration with the State Government can also conduct such tours, since they can present the best picture of their rich history, art and culture).

$\checkmark$ Encouraging Corporate Sponsorship for Heritage buildings: The Government already has in place concessions and subsidies for the same. However, there is a need to promote the policy and identify investors.

$\checkmark$ Conversion of palaces into heritage hotels: The state of Rajasthan has huge potential for heritage ecotourism. Outsourcing the maintenance and lighting of heritage monuments can help the state in utilizing this sector for improving ecotourism.

\section{REFERENCES}

Chakrabarty, P., \& Mandal, R. (2018). Geotourism mapping for sustainability: A basin-oriented approach. GeoJournal of Tourism and Geosites, vol. 21, no. 1, p.174-185.

Chandel, R. S. (2013). Role of Marketing Systems in Rural Development: Challenges and Prospects. Journal of Progressive Science, 4(2), 129-140.

Dorobantu, M. R., \& Nistoreanu, P. (2012). Rural Tourism and Ecotourism - the Main Priorities in Sustainable Development Orientations of Rural Local Communities in Romania. Economy Transdisciplinary Cognition, 15(1), 3-10.

Erlet Cater, (1993). Ecotourism in The Third World: Problems for Sustainable Tourism Development. In Tourism Management, 14(2), 85-90.

Fennell, D. A. (2015). Ethics in Tourism, pp. 45-57.

Jamal, T., \& Stronza, A., (2009). Collaboration theory and tourism practice in protected areas: stakeholders, structuring and sustainability. Journal of Sustainable Tourism, 17(2), 169-189.

Jhajharia, D., Singh, V. P., Kumar, R., \& Choudhary, R. R. (2014). Searching evidence for the existence of evaporation paradox in arid environments of northwest India. Global Nest Journal, 17(1), 3-11.

Kanga, S, Sharma, L K, Pandey, P C, Nathawat, M S, and Sharma, S K, (2013). Forest fire modeling to evaluate potential hazard to tourism sites using geospatial approach. Journ. Geomatics, vol. 7, No. 1, pp. 93-99, 2013.

Kanga, S., Thakur, K., Kumar, S., Gupta, H., Geo-informatics, A., Pradesh, H., Kumar, S. \& Gupta H. (2014). Potential of Geospatial Techniques to Facilitate the Tourist \& Administration: A Case Study of Shimla Hill Station, Himachal. Pradesh, India, International Journal of Advanced Remote sensing and GIS, 3(1), 681-698.

Liu, Z. (2003). Sustainable Tourism Development: A Critique. Journal of Sustainable Tourism, 11(6), 459-475

Raj Sharma, V., \& Bisht, K. (2018). Carrying capacity assessment and sustainable tourism management in Agra city, Uttar Pradesh (India). Geojournal of Tourism and Geosites, 25(2), 399-407.

Sharma, M. (2008). Forts of Rajasthan and Recent Tourist Inclinations. South Asian Journal of Tourism and Heritage, 1(1), 11-14.

Singh Chandel, R., \& Kanga, S. (2018). Use of Geospatial Techniques to Manage the Tourists \& Administration: A Case Study of Mount Abu, Rajasthan. We Int. J. Sci. Tech, 13(1), 63-78.

Singh, S.K., Chandel, V., Kumar, H., Gupta, H., (2017). RS \& GIS based urban land use change and site suitability analysis for future urban expansion of Parwanoo Planning area, Solan, Himachal Pradesh (India), International Journal of Development Research, 4 (8), 1491-1503.

Stausberg, M. (2012). Religion and tourism: Crossroads, destinations and encounters. London and New York: Routledge, xii, 292.

Strydom, A. J., Mangope, D., \& Henama, U. S. (2019). Making community-based tourism sustainable: Evidence from the Free State province, South Africa. Geojournal of Tourism and Geosites, 24(1), 7-18.

Terzidou, M., Stylidis, D., \& Szivas, E. M. (2008). Residents' perceptions of religious tourism and its socio-economic impacts on the Island of Tinos. Tourism and Hospitality, Planning and Development, 5(2), 113-129.

Wearing, S. (2011). Ecotourism and Environmental Sustainability: Principles and Practices. Tourism Management (Vol. 32).

Wearing, S., \& Neil, J. (2009). Ecotourism: Impact, potentials and possibilities (Second). ButterworthHeinemann is an imprint of Elsevier, 5177(01).

Submitted:

09.10.2019
Revised:

06.04.2020
Accepted and published online 14.04.2020 